\title{
Promising anitidiabetic potential of Cuscuta reflexa leaves methanol extract in alloxan- induced diabetic rats
}

Ronia Mostofa', Rayhana Begum ${ }^{1 *}$, Hongbin Wang ${ }^{2}$, Mst. Marium Begum³, Rubaba Karim', Taslima Begum', Nur Alam Siddiquee ${ }^{1}$, Rebeka Sultana ${ }^{4}$, Sonia Sultana ${ }^{1}$, A. K. Lutful Kabir ${ }^{5}$, Sumaiya Alam ${ }^{1,6}$ and Tasnuva Tasnim Nova $^{3}$

\begin{abstract}
Context: Cuscuta reflexa (C. reflexa) Roxb. (Convolvulaceae) has medicinal properties for the effective management of several aliments including diabetes mellitus, inflammation, and gastric ulcer.

Objective: The present investigation focuses on the antidiabetic potential of $C$. reflexa leaves methanol extract in alloxan-induced diabetic rats.

Materials and methods: The antidiabetic activity of C. reflexa leaves methanol extract (CRME) was evaluated using alloxan-induced diabetes in Wistar albino rats. The duration of the study was 45 days. Diabetic model was developed by i.p. administration of alloxan monohydrate (120 mg/kg). Ingestion of CRME (100, 200, and $400 \mathrm{mg} / \mathrm{kg} /$ day) and standard (gliclazide, $10 \mathrm{mg} / \mathrm{kg} /$ day) was done via oral route from the day of diabetes induction and continued up to 45 days. The effect of CRME was investigated by evaluating the blood glucose concentrations, $\mathrm{HbA}_{1 \mathrm{c}}$, insulin, lipid profile and liver function test. Further, the protective potentials of CRME were studied by histopathology of the pancreas, liver, and kidney tissues from experimental rats.

Results: CRME showed significant ( $p<0.01$ at all doses) reduction of blood glucose level $(137.1 \pm 5.8,125.9 \pm 6.5$, and $109.5 \pm 5.4 \mathrm{mg} / \mathrm{dL}$ at the doses of 100, 200, and $400 \mathrm{mg} / \mathrm{kg}$, respectively) as compared to the diabetic control (249.7 $\pm 7.3 \mathrm{mg} / \mathrm{dL}$ ). Moreover, CRME at the highest dose decreased $\mathrm{HbA}_{1 \mathrm{C}}$ and improved insulin levels (3.96\% and $11 \mathrm{ng} / \mathrm{ml}$, respectively) when compared with diabetic control group ( $7.55 \%$ and $6.5 \mathrm{ng} / \mathrm{ml}$, respectively). CRME also revealed pronounced improvement in liver function test and lipid profile test when compared to the diabetic control. Furthermore, CRME notably reversed the histopathological changes that observed in alloxan-induced diabetes.
\end{abstract}

Conclusion: Our research exertion clearly demonstrates that CRME can be explored as a substantial antidiabetic and organ protective agent in the management of diabetes.

Keywords: Antidiabetic, Alloxan monohydrate, $\mathrm{HbA}_{1 \mathrm{C}}$ Insulin, Lipid profile

\footnotetext{
*Correspondence: rayhana_kushum@yahoo.com

${ }^{1}$ Department of Pharmacy, Primeasia University, Dhaka 1213, Bangladesh

Full list of author information is available at the end of the article
}

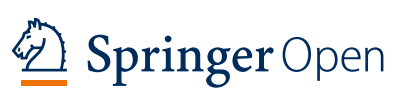

(c) The Author(s). 2020 Open Access This article is licensed under a Creative Commons Attribution 4.0 International License, which permits use, sharing, adaptation, distribution and reproduction in any medium or format, as long as you give appropriate credit to the original author(s) and the source, provide a link to the Creative Commons licence, and indicate if changes were made. The images or other third party material in this article are included in the article's Creative Commons licence, unless indicated otherwise in a credit line to the material. If material is not included in the article's Creative Commons licence and your intended use is not permitted by statutory regulation or exceeds the permitted use, you will need to obtain permission directly from the copyright holder. To view a copy of this licence, visit http://creativecommons.org/licenses/by/4.0/. 


\section{Introduction}

Diabetes mellitus is a common disorder of carbohydrate, fat, and protein metabolism in which the circulating glucose concentration is increased and it causes complications such as retinopathy, microangiopathy, neuropathy, and nephropathy [1,2]. This affects the metabolism of biomolecules (carbohydrate, protein, and lipid) together with injuring $\beta$-cells of pancreas and in some cases liver and kidney [3]. Diabetes is becoming one of the major causes of the global rise in morbidity and disabled people [4]. The insulin deficiency in diabetes mellitus gives rise to hyperlipidemia and fatty liver which eventually elevates the risk of heart disease and stroke [5]. Cardiovascular disease (CVD) is a major cause of death and disability among people with diabetes [6]. A good number of oral hypoglycemic agents and insulin have been used for the treatment of diabetes mellitus. However, the adverse effects of these synthetic hypoglycemic agents sometime result in disturbances of liver, kidney, hematological failure, and even coma $[5,7,8]$. Research and development of new remedies for diabetes are, therefore, in great demand. According to the demonstration of the previous studies, natural drugs have wide spread use in the practice of traditional medicine due to their curative values for various ailments [9-11]. However, more than 1200 plants have been described to be experimentally or ethnopharmacologically used to treat diabetes [12]. Based on the WHO recommendations, hypoglycemic agents of plant origin are important and warrant attention [13]. As a result, many conventional drugs have been derived from prototypic molecules in medicinal plants for the treatment of diabetes. At present there is a growing demand for herbal medicines worldwide and many pharmaceutical companies in Asia and Australia are conducting extensive phytochemical research on plant material to evaluate their medicinal value [14].

Cuscuta reflexa (C. reflexa) Roxb. (Cuscutaceae) is known as giant dodder in English and "swarna lota" in Bangladesh $[15,16]$. This plant species is largely distributed in India, China, Bangladesh, Eastern Asia, and Afghanistan [15]. C. reflexa contains a variety of phytoconstituents for which it has a long history of ethnomedicinal use $[17,18]$. The pharmacological activities of $C$. reflexa involve antiprotozoal, antimicrobial, antiproliferative, anticovulsant, antihypertensive, hepatoprotective, antioxidant, anti-inflammatory, and antipyretic properties $[15,19-23]$. The extract of $C$. reflexa holds a promising contribution in the folk medicine of Bangladesh to control blood sugar in patients suffering from diabetes mellitus [24, 25]. According to previous reports, $C$. reflexa exhibited significant hypoglycemic response in oral glucose tolerance tests in animal models [24, 26]. Therefore, the present investigation was aimed to focus on antidiabetic and organ protective effects of C. reflexa methanol extract (CRME) in Wistar albino rats to support the traditional and previous scientific claim.

\section{Materials and methods \\ Plant material}

C. reflexa fresh leaves were collected from Banani, Dhaka during May-June 2016. The identity of the plants was authenticated by from the National Herbarium of Bangladesh, Dhaka and the voucher specimen was deposited (no. 43780).

\section{Chemicals}

Gliclazide (API) was obtained from Drug International Ltd. Bangladesh. Alloxan monohydrate, chemical used to induce diabetes, was purchased from Sigma Aldrich Chemicals, Germany and all other chemicals (analytical grade) were purchased from Merck (Darmstadt, Germany).

\section{Extraction of plant material}

The collected leaves of $C$. reflexa were washed down with tap water appropriately and then shade dried and grinded into coarse powder. About $600 \mathrm{~g}$ of coarse powder of C. reflexa was soaked with $1.8 \mathrm{~L}$ methanol for 14 days in a conical flask. This was followed by filtration and the filtrate was subjected drying using rotary evaporator at $45^{\circ} \mathrm{C}$. Later, it was air dried for few days to evaporate solvent residue. Finally, the extract of $C$. reflexa was weighed $(35.7 \mathrm{~g})$ and stored in an air tight humidity protected borosilicate glass container.

\section{Phytochemical screening}

A number of qualitative chemical tests were performed to establish the phytochemical profile of CRME by using the standard procedures [27].

\section{Experimental animals}

Wistar albino rats of either sex weighing between 140 to $150 \mathrm{~g}$ have been used for the present experiment. Animals were kept in polypropylene cages where each cage contained six rats. The environment of the animal house was maintained at $12 \mathrm{~h} \mathrm{light} /$ dark cycle and $25 \pm 2{ }^{\circ} \mathrm{C}$. Before perusing the experiment, one week of acclimatization of animals was done allowing free access to feed and water. During surgery all animals were euthanized via anesthesia using isoflurane $(5 \%$ in $100 \%$ oxygen). The present research protocols as well as animal care were observed according to the guidelines of Guide for the Care and Use of Laboratory Animals (NIH publication No: 85-23, revised in 1985). The experimental procedures for our study have been approved by the Biomedical Research Center, University of Dhaka, Bangladesh (Ref. no. DPT/BMRC/2016-2017/467). 


\section{Induction of diabetes}

Body weight and fasting blood glucose level of animals were measured before inducing diabetes. Animals with very low or high glucose levels were discarded for experimentation. Diabetes was induced by a sole dose of $120 \mathrm{mg} / \mathrm{kg}$ of alloxan monohydrate via intraperitoneal route of each animal. The induction of diabetes was confirmed by measuring fasting serum glucose level after 3 days using accu chek glucometer. Animals with blood glucose level of $>200$ to $<280 \mathrm{mg} / \mathrm{dL}$ have been selected for the present study. Diabetic rats were randomly grouped and each group consisted of six rats. Treatments for 45 days in all groups were started 3 days after alloxan monohydrate injection [28]. The groups of experimental animals and treatment pattern for the present study have been represented as follows:

\begin{tabular}{ll}
\hline Groups & Treatment \\
Group I & Healthy control rats. \\
$\begin{array}{ll}\text { Group } & \text { Alloxan-induced diabetic rats. } \\
\text { II } & \\
\text { Group } & \text { Alloxan-induced diabetic rats administered gliclazide at the } \\
\text { III } & \text { dose of } 10 \mathrm{mg} / \mathrm{kg}, \text { p.o. once daily. } \\
\text { Group } & \text { Alloxan-induced diabetic rats administered CRME at the dose } \\
\text { IV } & \text { of } 100 \mathrm{mg} / \mathrm{kg}, \text { p.o. once daily. } \\
\text { Group } & \text { Alloxan-induced diabetic rats administered CRME at the dose } \\
\text { V } & \text { of } 200 \mathrm{mg} / \mathrm{kg}, \text { p.o. once daily. } \\
\text { Group } & \text { Alloxan-induced diabetic rats administered CRME at the dose } \\
\text { VI } & \text { of } 400 \mathrm{mg} / \mathrm{kg}, \text { p.o. once daily. }\end{array}$ \\
\hline
\end{tabular}

Fasting blood glucose was measured periodically on days $9,18,27,36$, and 45 . After 45 days of treatment, blood samples were collected from rat by cardiac puncture under anesthesia with 5\% isoflurane in presence of $100 \%$ oxygen. The serum was collected by centrifugation at $5000 \mathrm{rpm}$ for $5 \mathrm{~min}$.

\section{Evaluation of $\mathrm{HbA}_{1 \mathrm{c}}$ level}

$\mathrm{HbA}_{1 \mathrm{C}}$ level in rat blood and the percentage of $\mathrm{HbA}_{1 \mathrm{c}}$ in total hemoglobin were determined by using standard procedure of Nathan et al. (1984) [29]..

\section{Evaluation of insulin level}

The concentration of insulin was examined using Rat insulin enzyme-linked immunosorbent assay Kit (RayBiotech Inc. Norcross, GA, USA).

\section{Evaluation of lipid profile}

Serum was separated and the observed lipid profile includes: triglycerides, HDL, LDL, and total cholesterol by using a previously established method [30].

\section{Evaluation of liver function}

Serum alanine aminotransferase (ALT), alkaline phosphatase (ALP), aspartate aminotransferase (AST), and total bilirubin levels have been estimated by using standard test procedure [31].

\section{Histological observation and evaluation}

For histological examination tissues from pancreas, liver, and kidney from rats of different groups have been fixed in freshly prepared $10 \%$ neutral buffered formalin. Tissue specimens were processed for paraffin embedding tissue sections ( $5 \mu \mathrm{m}$ thick), stained with Hematoxyline and Eosin prior to histopathological evaluation. All sections were examined under light microscope. Photographs of the lesions were taken with an Olympus photo microscope for observation and documentation of histopathological changes.

\section{Data analysis}

All experimental data obtained were presented as mean \pm S.E.M, and statistical analysis was done by finding the significance among treated and control groups using One Way Analysis of Variance (ANOVA, version 3.0), followed by Dunnett's test. $P<0.05$ was considered as significant value.

\section{Results \\ Phytochemical screening}

The phytochemical tests of CRME revealed the existence of alkaloids, flavonoids, steroids, terpinoids, cumarin, anthraquinones, saponins, and carbohydrates.

\section{Effect of CRME extract on body weight}

According to the Table 1, body weight of untreated diabetic model was significantly decreased (22.79\%). However, on day 45 the weight of the CRME treated rats were increase to $2.96 \%, 4.85 \%$, and $7.81 \%$ at the doses of 100,200 , and $400 \mathrm{mg} / \mathrm{kg}$, respectively.

\section{Effect of CRME extract on blood glucose concentration}

Antidiabetic activity of CRME was assessed in alloxaninduced diabetic rats. Injection of alloxan significantly increased $(p<0.01)$ the blood glucose concentration in all groups when compared with the healthy control group (Table 2). However, treatment with CRME and gliclazide demonstrated noteworthy downregulation of blood glucose concentration in comparison to the diabetic control group from the 18th day onwards. The continuous treatment for 45 days leads to pronounced reduction $(p<0.01$ at all doses $)$ in blood glucose concentration as compared with the diabetic control group. At the end of the study, gliclazide $(10 \mathrm{mg} / \mathrm{kg})$ treated group showed $59.09 \%$ inhibition when compared with the initial blood glucose level measured on day 0 (258.4 \pm 8.4 
Table 1 Effect of CRME on body weight variation

\begin{tabular}{|c|c|c|c|c|}
\hline \multirow[t]{2}{*}{ Groups } & \multicolumn{4}{|c|}{ Body weight variation (g) } \\
\hline & $\begin{array}{l}\text { Initial } \\
\text { Body Weight (g) }\end{array}$ & $\begin{array}{l}\text { Final } \\
\text { Body Weight (g) }\end{array}$ & Change in Body Weight (g) & Change in Body Weight (\%) \\
\hline Group I & $142.5 \pm 6.9$ & $159.2 \pm 4.4$ & 16.7 & 11.72 \\
\hline Group II & $145.7 \pm 5.4$ & $112.5 \pm 5.0$ & 33.2 & 22.79 \\
\hline Group III & $147.4 \pm 6.1$ & $161.3 \pm 3.9$ & 13.9 & 9.43 \\
\hline Group IV & $141.5 \pm 4.8$ & $145.7 \pm 3.7$ & 4.2 & 2.96 \\
\hline Group V & $148.6 \pm 4.5$ & $155.8 \pm 5.6$ & 7.2 & 4.85 \\
\hline Group VI & $143.3 \pm 5.3$ & $154.5 \pm 4.3$ & 11.2 & 7.81 \\
\hline
\end{tabular}

Each value stands for mean \pm S.E.M $(n=6)$. Group I = Healthy control, Group II = Diabetic control, Group III = Diabetic control + $10 \mathrm{mg} / \mathrm{kg}$ of gliclazide, Group IV = Diabetic control $+100 \mathrm{mg} / \mathrm{kg}$ CRME, Group V = Diabetic control $+200 \mathrm{mg} / \mathrm{kg}$ CRME, Group VI = Diabetic control $+400 \mathrm{mg} / \mathrm{kg}$ CRME

$\mathrm{mg} / \mathrm{dL}$ ). On the other hand, CRME at the dose of 400 $\mathrm{mg} / \mathrm{kg}$ reduced blood glucose level $55.39 \%$ as compared to the initial blood glucose level measured on day 0 $(245.5 \pm 9.5 \mathrm{mg} / \mathrm{dL})$ and the inhibition is comparable to the reference drug, gliclazide.

\section{Effects of CRME on glycosylated hemoglobin and insulin levels}

Figure 1a \& b portrayed the variation in glycosylated hemoglobin and insulin levels, respectively. The concentration of glycosylated hemoglobin level increased significantly in diabetic control group as compared to healthy control group $(p<0.01)$. On the other hand, administration of CRME in diabetic rats significantly decreases the glycosylated hemoglobin level as compared to diabetic control group $(p<0.05, p<0.01$, and $p<0.01$ at the doses of 100, 200, and $400 \mathrm{mg} / \mathrm{kg}$, respectively).

Insulin concentration in diabetic control decreased significantly compared to healthy control group ( $\mathrm{p}<$ 0.01). However, treatment with CRME at the higher doses in diabetic rats revealed a noteworthy upregulation of insulin level in comparison with untreated diabetic group $(\mathrm{p}<0.05$ and $\mathrm{p}<0.01$ at the doses of 200 and $400 \mathrm{mg} / \mathrm{kg}$, respectively).

\section{Effect of CRME on lipid profiles}

Table 3 showed the lipid profiles of healthy control, diabetic control, gliclazide and CRME treated groups. In diabetic rats there was a significant increase in total cholesterol, triglycerides, LDL level $(p<0.01)$ and significant decrease in HDL level $(p<0.01)$ in serum as compared with healthy control. However, administration of CRME demonstrated noteworthy reduction in total cholesterol $(p<0.01$ at all doses), triglycerides $(p<0.01$ at all doses), LDL-cholesterol ( $p<0.01$ at all doses), and significant increase in HDL-cholesterol $(p<0.01$ at all doses) on day 45 in comparison with the diabetic rats. Moreover, treatment with CRME at the highest dose ( $400 \mathrm{mg} / \mathrm{kg}$ ) revealed decreases in TC by $43.11 \%$, TG by $46.40 \%$, and LDL by $55.61 \%$ whereas improved HDL by $111.8 \%$ as compared to diabetic rats.

\section{Effect of CRME on liver function test}

In diabetic model, a significant increase $(p<0.01)$ in the enzymatic activities of ALT, ALP, AST, and the serum bilirubin level was found as compared with the normal levels (Table 4). On the contrary, CRME revealed a significant reduction in the activities of ALT $(p<0.05$, $p<0.05$, and $p<0.01$ at the doses of 100, 200, and 400

Table 2 Effect of CRME on blood glucose level

\begin{tabular}{|c|c|c|c|c|c|c|}
\hline \multirow[t]{2}{*}{ Groups } & \multicolumn{6}{|c|}{ Blood glucose level in mg/dL } \\
\hline & Day 0 & Day 9 & Day 18 & Day 27 & Day 36 & Day 45 \\
\hline Group I & $80.4 \pm 2.3$ & $81.0 \pm 2.4$ & $79.2 \pm 3.4$ & $85.8 \pm 4.5$ & $88.6 \pm 3.4$ & $81.2 \pm 4.3$ \\
\hline Group II & $237.9 \pm 7.6^{\mathrm{a}^{* *}}$ & $245.2 \pm 8.9^{\mathrm{a}^{* *}}$ & $251.7 \pm 8.1^{a^{* *}}$ & $248.8 \pm 7.5^{\mathrm{a}^{* *}}$ & $253.4 \pm 8.3^{\mathrm{a}^{* *}}$ & $249.7 \pm 7.3^{3^{* *}}$ \\
\hline Group III & $258.4 \pm 8.4^{\mathrm{a}^{* *}}$ & $209.7 \pm 8.1^{b^{*}}$ & $162.9 \pm 8.5^{\mathrm{b}^{* *}}$ & $138.5 \pm 6.9^{b^{* *}}$ & $125.7 \pm 7.4^{b^{* *}}$ & $105.7 \pm 5.4^{4^{* * *}}$ \\
\hline Group IV & $244.1 \pm 9.2^{\mathrm{a}^{* *}}$ & $227.2 \pm 9.7^{\mathrm{bn}}$ & $215.7 \pm 7.6^{b^{*}}$ & $190.8 \pm 8.2^{b^{* *}}$ & $165.1 \pm 7.8^{b^{* *}}$ & $137.1 \pm 5.8^{b^{* *}}$ \\
\hline Group V & $267.2 \pm 10.4^{\mathrm{a}^{* *}}$ & $215.8 \pm 9.9^{\mathrm{bn}}$ & $193.9 \pm 9.1^{b^{* *}}$ & $166.3 \pm 6.7^{b^{* *}}$ & $145.9 \pm 6.5^{b^{* *}}$ & $125.9 \pm 6.5^{b^{* *}}$ \\
\hline Group VI & $245.5 \pm 9.5^{\mathrm{a}^{* *}}$ & $198.8 \pm 10.1^{b^{* *}}$ & $175.1 \pm 8.9^{\mathrm{b}^{* *}}$ & $140.6 \pm 7.8^{b^{* *}}$ & $133.5 \pm 6.4^{b^{* *}}$ & $109.5 \pm 5.4^{4^{* *}}$ \\
\hline
\end{tabular}

All values were expressed as mean \pm S.E.M $(n=6)$. $\left.{ }^{*}\right)$ designates statistically significant difference from the respective group $\left(^{* *} p<0.01\right)$ whereas $(\eta)$ designates statistically no significant difference from the relevant group $(p>0.05)$ using ANOVA, followed by Dunnett's multiple comparison test. $a=$ while compared with healthy control, $\mathrm{b}=$ while compared with diabetic control. Group I = Healthy control, Group II = Diabetic control, Group III = Diabetic control $+10 \mathrm{mg} / \mathrm{kg}$ of gliclazide, Group IV = Diabetic control $+100 \mathrm{mg} / \mathrm{kg}$ CRME, Group V = Diabetic control $+200 \mathrm{mg} / \mathrm{kg}$ CRME, Group VI = Diabetic control $+400 \mathrm{mg} / \mathrm{kg}$ CRME 


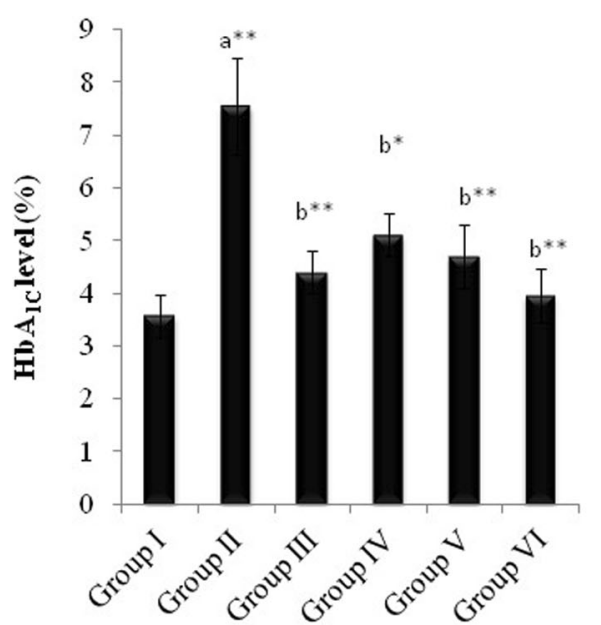

a

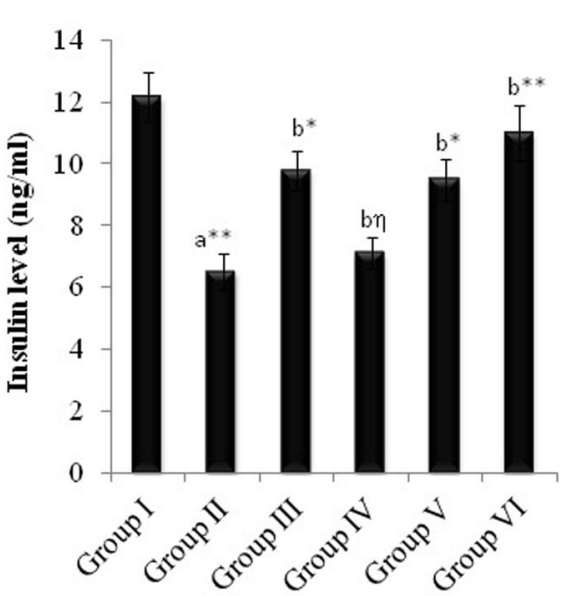

b

Fig. 1 Effect of C. reflexa methanol extract (CRME) on $\mathrm{HbA}_{1 \mathrm{C}}(\mathbf{a})$ and insulin level (b). All values were expressed as mean \pm S.E.M $(n=3)$. ${ }^{*}$ ) designates statistically significant difference from the respective group $\left({ }^{*} p<0.01\right)$ whereas $(\eta)$ indicates statistically no significant difference from the relevant group $(p>0.05)$ using ANOVA, followed by Dunnett's multiple comparison test. $\mathrm{a}=$ while compared with healthy control, $\mathrm{b}=$ while compared with diabetic control. Group I= Healthy control, Group II = Diabetic control, Group III= Diabetic control + 10 mg/kg of gliclazide, Group IV = Diabetic control + 100 mg/kg CRME, Group V= Diabetic control + 200 mg/kg CRME, Group VI= Diabetic control + 400 mg/kg CRME

$\mathrm{mg} / \mathrm{kg}$, respectively), ALP $(p<0.05, p<0.01$, and $p<0.01$ at the doses of 100,200 , and $400 \mathrm{mg} / \mathrm{kg}$, respectively), AST $(p<0.01, p<0.01$, and $p<0.01$ at the doses of 100 , 200 , and $400 \mathrm{mg} / \mathrm{kg}$, respectively), and serum total bilirubin level $(p<0.01, p<0.01$, and $p<0.01$ at the doses of 100, 200, and $400 \mathrm{mg} / \mathrm{kg}$, respectively) in comparison to the untreated diabetic rats. Moreover, treatment with CRME at the highest dose $(400 \mathrm{mg} / \mathrm{kg})$ revealed inhibition in ALT by $38.05 \%$, ALP by $55.13 \%$, AST by $68.56 \%$ and bilirubin by $58.99 \%$ as compared to diabetic rats.

\section{Effect of CRME on histopathology of pancreas, liver, and kidney \\ Pancreas}

Healthy control rat exhibited usual histological architecture (Fig. 2a). However, alloxan-induced cellular damage to the pancreas, areas of cell necrosis $(\mathrm{CN})$, numerous fatty tissue deposition, and inflammatory cells infiltrations in diabetic control group when compared with the healthy group (Fig. 2b). On the other hand, oral administration of CRME at the doses of 100 and $200 \mathrm{mg} /$ $\mathrm{kg}$, conserved cell architecture and demonstrated moderate inflammatory cell infiltration, and fatty tissue deposition, which is an improvement from what occurred in the untreated alloxan-induced diabetic rats (Fig. 2d \& e). Further normal architecture was maintained in gliclazide and CRME (400 mg/kg, p.o.) treated groups (Fig. 2c \& f, respectively) but the group treated with gliclazide $(10 \mathrm{mg} /$ $\mathrm{kg}$, p.o.) showed deposition of fatty tissue.

\section{Liver}

Figure 3a showed the histology of the liver tissue of healthy control group. However, the histology of liver

Table 3 Effect of CRME on serum lipid profile

\begin{tabular}{|c|c|c|c|c|}
\hline \multirow[t]{2}{*}{ Groups } & \multirow[b]{2}{*}{ TG } & \multicolumn{3}{|c|}{ Serum lipid profile (mg/dl) } \\
\hline & & $\mathrm{HDL}$ & LDL & TC \\
\hline Group I & $72.54 \pm 3.1$ & $49.89 \pm 2.9$ & $27.81 \pm 1.9$ & $110.23 \pm 3.5$ \\
\hline Group ॥ & $140.66 \pm 5.2^{\mathrm{a}^{* *}}$ & $22.40 \pm 1.6^{\mathrm{a}^{* *}}$ & $110.50 \pm 4.7^{\mathrm{a}^{* *}}$ & $205.90 \pm 5.5^{a^{* *}}$ \\
\hline Group III & $122.00 \pm 3.0^{\mathrm{b}^{*}}$ & $33.68 \pm 1.8^{\mathrm{b}^{* *}}$ & $83.90 \pm 3.2^{b^{* *}}$ & $145.61 \pm 4.8^{\mathrm{b}^{* *}}$ \\
\hline Group IV & $105.25 \pm 3.9^{b^{* *}}$ & $32.27 \pm 2.5^{\mathrm{b}^{* *}}$ & $85.50 \pm 2.9^{b^{* *}}$ & $155.55 \pm 4.5^{b^{* *}}$ \\
\hline Group V & $87.50 \pm 3.1^{b^{* *}}$ & $38.50 \pm 3.3^{b^{* *}}$ & $65.45 \pm 2.7^{b^{* *}}$ & $131.39 \pm 3.9^{b^{* *}}$ \\
\hline Group VI & $75.40 \pm 3.2^{b^{* *}}$ & $47.45 \pm 3.0^{b^{* *}}$ & $49.05 \pm 2.0^{b^{* *}}$ & $117.14 \pm 4.0^{b^{* *}}$ \\
\hline
\end{tabular}

All values were expressed as mean \pm S.E.M $(n=3)$. $\left(^{*}\right)$ indicates statistically significant difference from the respective group $\left(^{* *} p<0.01\right)$ using ANOVA, followed by Dunnett's multiple comparison test. $\mathrm{a}=$ when compared with healthy control, b= when compared with diabetic control. Group I = Healthy control, Group II = Diabetic control, Group III = Diabetic control $+10 \mathrm{mg} / \mathrm{kg}$ of gliclazide, Group IV = Diabetic control $+100 \mathrm{mg} / \mathrm{kg}$ CRME, Group V = Diabetic control $+200 \mathrm{mg} / \mathrm{kg}$ CRME, Group VI = Diabetic control $+400 \mathrm{mg} / \mathrm{kg}$ CRME 
Table 4 Effect of CRME on Liver function test

\begin{tabular}{|c|c|c|c|c|}
\hline \multirow[t]{2}{*}{ Groups } & \multicolumn{4}{|c|}{ Liver function test } \\
\hline & $\mathrm{ALT}(\mathrm{U} / \mathrm{l})$ & $\operatorname{ALP}(\mathrm{U} / \mathrm{l})$ & $\mathrm{AST}(\mathrm{U} / \mathrm{l})$ & Bilirubin (mg/dl) \\
\hline Group I & $51.95 \pm 2.4$ & $35.50 \pm 3.1$ & $105.50 \pm 3.9$ & $0.49 \pm 0.04$ \\
\hline Group II & $79.50 \pm 3.7^{7^{* *}}$ & $87.70 \pm 4.1^{1^{* *}}$ & $226.45 \pm 6.9^{\mathrm{a}^{* *}}$ & $1.39 \pm 0.07^{\mathrm{a}^{* *}}$ \\
\hline Group III & $73.15 \pm 3.0^{\mathrm{bn}}$ & $80.45 \pm 4.3^{\mathrm{bn}}$ & $195.08 \pm 5.4^{\mathrm{b}^{*}}$ & $1.28 \pm 0.06^{\mathrm{bn}}$ \\
\hline Group IV & $60.55 \pm 3.9^{b^{*}}$ & $70.55 \pm 4.1^{b^{*}}$ & $135.15 \pm 6.6^{\mathrm{b}^{* *}}$ & $0.75 \pm 0.03^{b^{* *}}$ \\
\hline Group V & $55.40 \pm 3.3^{\mathrm{b}^{*}}$ & $54.80 \pm 3.1^{\mathrm{b}^{* *}}$ & $96.45 \pm 4.1^{\mathrm{b}^{* *}}$ & $0.63 \pm 0.04^{b^{* *}}$ \\
\hline Group VI & $49.25 \pm 3.7^{b^{* *}}$ & $39.35 \pm 3.8^{b^{* *}}$ & $71.19 \pm 3.4^{b^{* *}}$ & $0.57 \pm 0.02^{\mathrm{b}^{* *}}$ \\
\hline
\end{tabular}

All values were expressed as mean \pm S.E.M $(n=3) .\left(^{*}\right)$ indicates statistically significant difference from the respective group $\left(^{* *} p<0.01\right)$ whereas $(\eta)$ indicates statistically no significant difference from the respective group $(p>0.05)$ using ANOVA, followed by Dunnett's multiple comparison test. $a=$ while compared with healthy control, $b=$ while compared with diabetic control. Group I = Healthy control, Group II = Diabetic control, Group III = Diabetic control $+10 \mathrm{mg} / \mathrm{kg}$ of gliclazide, Group IV = Diabetic control + $100 \mathrm{mg} / \mathrm{kg}$ CRME, Group V = Diabetic control $+200 \mathrm{mg} / \mathrm{kg}$ CRME, Group VI = Diabetic control $+400 \mathrm{mg} / \mathrm{kg}$ CRME

tissue from the diabetic rat revealed cell necrosis, expansion, and thickening of the walls of veins, capillaries, and progression of fibrosis (Fig. 2b). However, this was not the case for those treated with CRME at the doses of 200 and $400 \mathrm{mg} / \mathrm{kg}$, p.o. (Fig. 3e \& $\mathrm{f}$, respectively). In these instances, the liver tissues were compact and healthy. On the other hand, group treated with gliclazide and CRME $(100 \mathrm{mg} / \mathrm{kg}$, p.o.) illustrated moderate cellular necrosis and infiltration of inflammatory cells in the central vein (Fig. 3c \& d, respectively).

\section{Kidney}

Kidney histological structure was normal in the healthy control group (Fig. 4a). Alloxan-induced diabetic group showed presence of destructed glomeruli and infiltration of inflammatory cells (Fig. 4b). Groups treated with CRME showed improvements in the tissue architecture and more visible glomeruli and moderate inflammatory cells were observed (Fig. 4d \& e). However, group treated with methanol extract of C. reflexa at the dose of $400 \mathrm{mg} / \mathrm{kg}$ significantly reduced the pathological destructions (Fig. 4f). On the other hand, group treated with gliclazide $(10 \mathrm{mg} /$

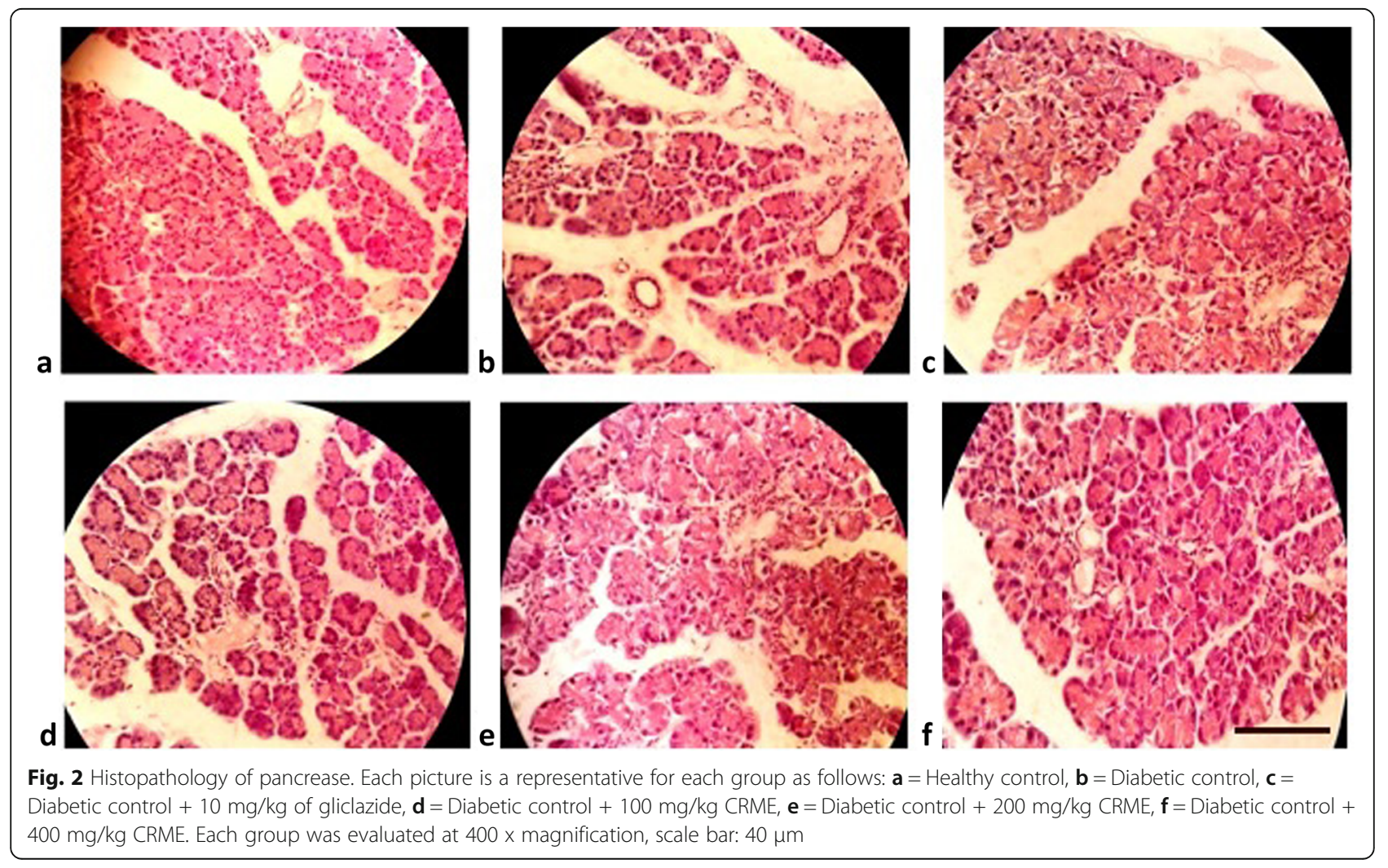


a
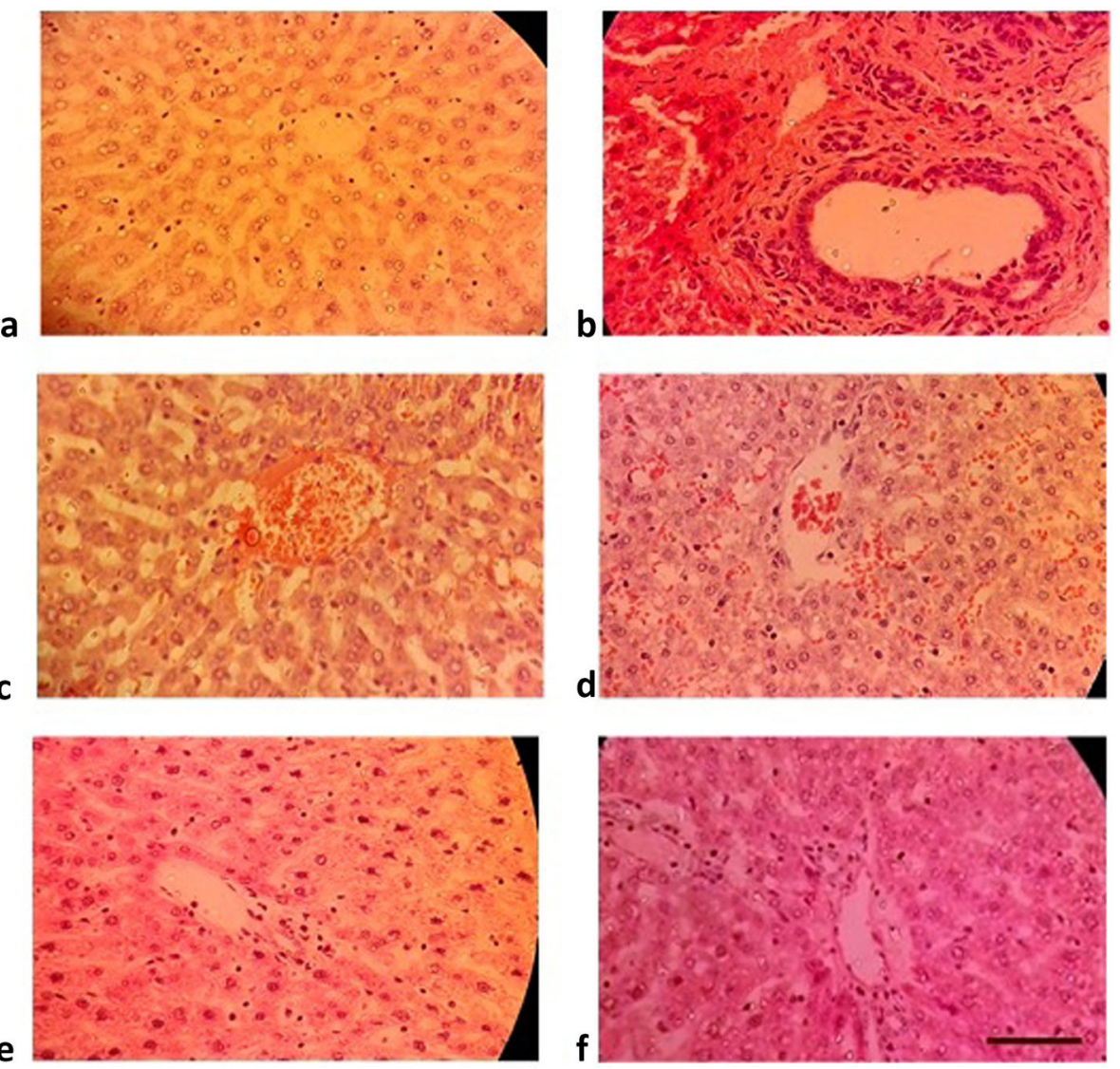

Fig. 3 Histopathology of liver. Each picture is a representative for each group as follows: $\mathbf{a}=$ Healthy control, $\mathbf{b}=$ Diabetic control, $\mathbf{c}=$ Diabetic control $+10 \mathrm{mg} / \mathrm{kg}$ of gliclazide, $\mathbf{d}=$ Diabetic control $+100 \mathrm{mg} / \mathrm{kg}$ CRME, $\mathbf{e}=$ Diabetic control $+200 \mathrm{mg} / \mathrm{kg}$ CRME, $\mathbf{f}=$ Diabetic control +400 $\mathrm{mg} / \mathrm{kg}$ CRME. Each group was evaluated at $400 \times$ magnification, scale bar: $40 \mu \mathrm{m}$

kg, p.o.) showed moderate destructed glomeruli and infiltration of inflammatory cells (Fig. 4c).

\section{Discussion}

On phytochemical screening, CRME demonstrated the presence of alkaloids, tannins, steroids, terpinoids, cumarins, anthraquinones, saponins, and flavonoids. Many previous studies have reported that certain terpenoids, steroids, flavonoids, and phenolic compounds have defensive values against hyperglycemia with respect to their antioxidant properties [32, 33]. We hypothesized that phenolic compounds, alkaloids, flavonoids, and tannins in C. reflexa can be credited to their insulinotropic effect that enables the reduction of blood glucose levels due to their antidiabetic effect. Nevertheless, extensive phytochemical analysis must be needed to evaluate the therapeutically active compounds of $C$. reflexa. With antidiabetic, antiinflammatory, and antiulcer properties.

A large diversity of animal models has been developed to better understand the pathogenesis of insulin dependent diabetes and new drugs have been introduced into the market to treat the primary cause or to prevent the catastrophe of its complications [34]. Among these models, alloxan-induced diabetes model is by far the most frequently used model which has been useful for the study of multiple aspect of the disease [35-37]. Alloxan is a diabetogenetic, hepatotoxic, and nephrotoxic substance which by damaging the pancreatic beta cell membrane, fragmenting DNA, and reacting with enzymes, sharply decreases insulin levels and thereby increases glucose concentrations in animals [38].

The consequences of the present study pointed out that i.p. injection of alloxan destroyed beta cells in rats in which glucose level significantly increased compared to healthy control. However, blood glucose levels reduced in all experimental groups which received CRME. Moreover, the hypoglycemic effect of CRME was comparable to the standard drug, gliclazide. Gliclazide is a sulphonylurea oral hypoglycaemic agent used in the treatment of diabetes. It improves defective insulin secretion and inhibits glucogenolysis and gluconeogenesis in the liver. Through improving insulin binding to surface receptors, they also enhance the insulin sensitivity of target cells [39]. Furthermore, in vivo evidence revealed that gliclazide 

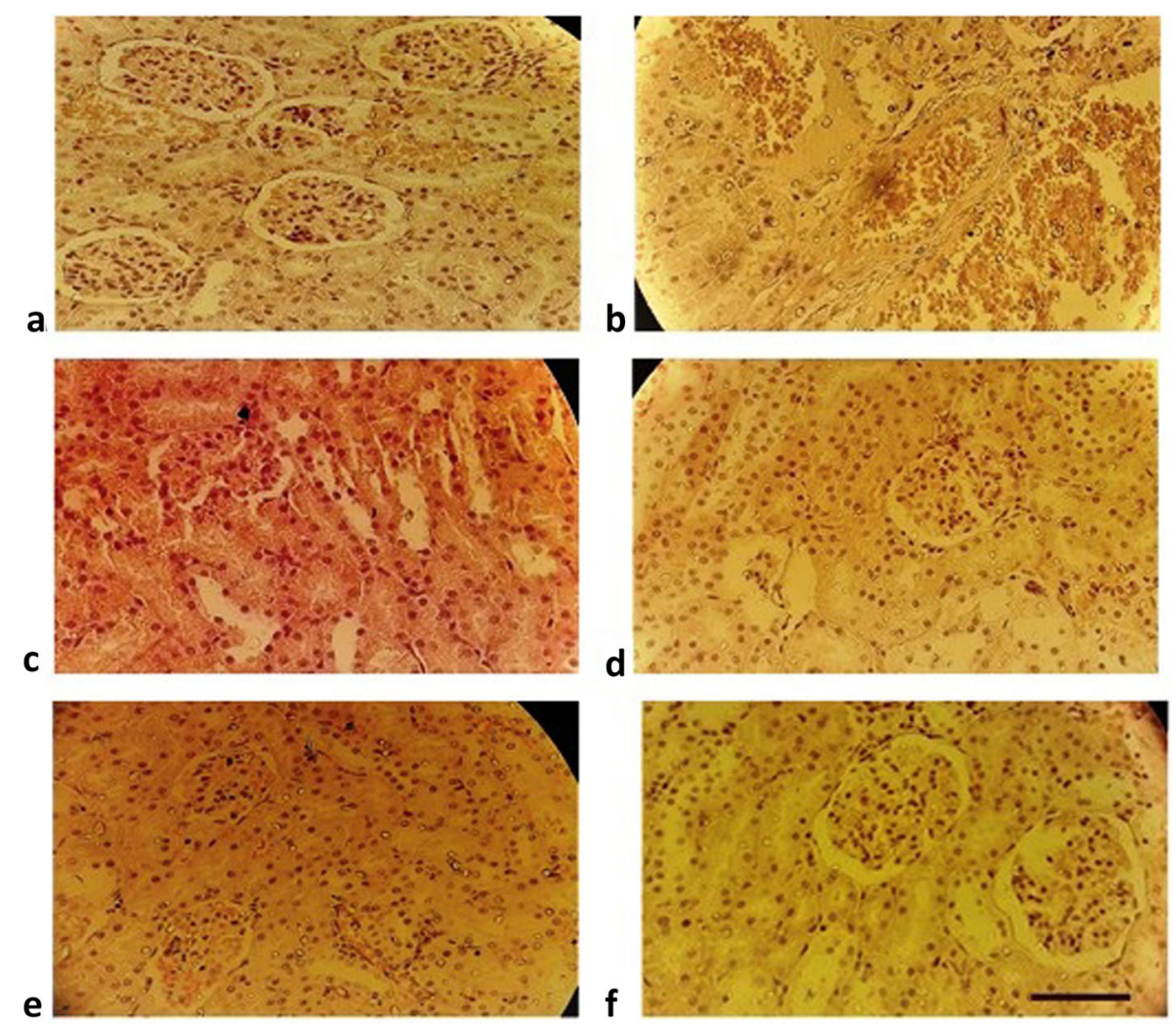

Fig. 4 Histopathology of kidney. Each picture is a representative for each group as follows: $\mathbf{a}=$ Healthy control, $\mathbf{b}=$ Diabetic control, $\mathbf{c}=$ Diabetic control $+10 \mathrm{mg} / \mathrm{kg}$ of gliclazide, $\mathbf{d}=$ Diabetic control $+100 \mathrm{mg} / \mathrm{kg}$ CRME, $\mathbf{e}=$ Diabetic control $+200 \mathrm{mg} / \mathrm{kg}$ CRME, $\mathbf{f}=$ Diabetic control +400 $\mathrm{mg} / \mathrm{kg}$ CRME. Each group was evaluated at 400 x magnification, scale bar: $40 \mu \mathrm{m}$

cause persisted hypoglycaemia in alloxan-induced diabetic rats [40].

CRME showed a dose dependent reduction of blood glucose concentration at the doses of 100, 200, and 400 $\mathrm{mg} / \mathrm{kg}$, p.o. while the standard gliclazide $(10 \mathrm{mg} / \mathrm{kg}$, p.o.) revealed a significant antidiabetic activity in alloxaninduced diabetes in continuous treatment for 45 days. However, at the end of the study, at the higher dose the normal blood sugar level was achieved by augmented hypoglycemic activity. Such activity of this extract could be due to the particular existence of phenolic, terpenoid, and flavonoid components within the plant parts.

In diabetic rats, the level of $\mathrm{HbA}_{1 \mathrm{C}}$ was increased due to the persistent hyperglycemia which results in glycation of hemoglobin. The concentration of $\mathrm{HbA}_{1 \mathrm{C}}$ is related to diabetic complications and it is considered as a tool for the diagnosis and prognosis of diabetes-associated complications $[41,42]$. Therefore, the measurement of glycosylated hemoglobin is supposed to be a very sensitive index for glycemic control. In the present study, the diabetic untreated rats had shown higher rates of hemoglobin glycosylation in comparison with the healthy group. However, administration of CRME significantly decreased the $\mathrm{HbA}_{1 \mathrm{C}}$ level as compared with diabetic group. The ability of CRME to bring about a significant decrease in $\mathrm{HbA}_{1 \mathrm{C}}$ level could be indicative of its potential ability to improve glycemic status and prevent the diabetic-associated complications in diabetic rats.

Moreover, the present results also revealed that alloxan causes a significant reduction in body weight after 45 days. These results promisingly correspond to the previously reported data [43-46]. All though the food intake is more in diabetic rats than normal healthy group, diabetic rats showed enough weight loss due to catabolism of fats and proteins. Under the circumstances of lack of insulin, the proteolysis causes decrease in protein content within the muscle tissues [44]. Notable mobilization of fat within the skeletal muscle of diabetic model caused significant weight loss as observed in our present investigation. Nonetheless, treating the diabetic model with CRME (200 and $400 \mathrm{mg} /$ $\mathrm{kg} /$ day $)$ or gliclazide $(10 \mathrm{mg} / \mathrm{kg} /$ day $)$ demonstrated small scale reduction of body weight and this might be either as a result of increase of insulin secretion in blood or elevated food consumption.

There is a significant role of lipids that is associated with the pathogenesis of diabetes mellitus. The rise in serum cholesterol, LDL, VLDL, triglycerides, and fall in serum HDL level is one of the significant factors for 
developing microvascular complication which leads to atherosclerosis and other heart diseases $[47,48]$ Increased level of triglycerides and LDL-cholesterol was noticed in diabetic rat model [49]. Increased cholesterol level in diabetic rats could be caused by elevated intestinal fat absorption and growing biosynthesis of cholesterol. Treatment with CRME considerably lowered total cholesterol, triglycerides, and LDL levels in serum as per the range of doses applied, while at the same time the beneficial HDL level was observed to rise significantly. Thus, the results of our present investigation clearly reveal that CRME recuperated the disparity of the lipid profile in diabetes-induced rat model as per dose dependent manner.

xIn our study, the enzymatic actions of ALT, ALP, and AST as well as serum bilirubin level were upregulated in diabetic group. Evidence demonstrated that the changes in the levels of ALT, ALP, AST, and bilirubin in diabetic rats are associated with the changes in the rate of metabolic reactions catalyzed by these enzymes. The elevation of transaminases activities occur in scarcity of insulin, due to availability of amino acids, in the blood of diabetes mellitus patients [50]. Such circumstances lead to increased gluconeogenesis and ketogenesis. The recovery of AST and ALT to their normal levels was found in the groups of experimental animals treated with CRME. Serum levels of these enzymes function as biomarker of liver activity as a result of restoration of normal level of these enzymes specify normal functioning of liver. Elevated enzymatic activities of ALP have always been reported in alloxan-induced diabetic model. The enhanced activity of ALP in diabetic model is probably due to the occurrence of cell damage by altered cell membrane morphology. Serum ALP, bilirubin, and total protein levels are associated with the activities of liver cell. The rise in serum ALP level occurs due to growing rate of synthesis under inflation of biliary pressure [51].

Alloxan caused a signifcant elevation in enzyme levels such as ALT, ALP, AST, and bilirubin levels when compared to control. There was a significant restoration of these enzyme levels on the administration of CRME in a dose-dependent manner. However, there was nonsignificant reduction of ALP and total bilirubin concentrations in group treated with gliclazide in comparison to the diabetic control group.

The data from histopathological examination of pancreas of diabetic model exhibited islet of Langerhans with infiltration of inflammatory cell and distorted pancreas. Oral ingestion of CRME recovered the altered architecture of the pancreas to normal conformation. Moreover, the damaged structure and numerous inflammatory cells have been observed in the liver tissues of diabetic rats. These constructive changes in the hepatic cells were restored in diabetic rats treated with CRME in a dose dependent manner. Furthermore, the damaged glomeruli and numerous inflammatory cells have been noticed in the renal tissues of diabetic model. These injured tissues regained their normal conformation when treated with CRME. As per the results of microscopic examinations, the severity of pancreatic, hepatic, and renal lesions in diabetic animals extensively declined and considerably recovered by the treatment of CRME at medium to higher doses.

\section{Conclusion}

Monitoring medicinal plants for biological activity is believed to be one of the key subjects to demonstrate the pharmacological action of the drug. Manifestation of drug's safety and efficacy with respect to its purpose of use is necessary. For this reason a constructive and progressive order of preclinical (animal) and clinical (human) studies must be performed.

New therapeutic innovations that are dedicated to prevent DM and DM complications are of interest. Our study distinguished the antidiabetic and tissue protective potentials of methanol extract of $C$. reflexa. Thus, the multifactorial activity of $C$. reflexa would be a new alternative therapeutic agent for the treatment of DM as well as its complications. This study indicated methanol extract of C. reflexa have potential to decrease blood glucose, $\mathrm{HBA}_{1 \mathrm{c}}$, and insulin concentrations. In addition, the present treatment improved complications associated with experimental diabetes. Hence, the present study supports the traditional usefulness of this plant in the treatment of diabetes mellitus. In conclusion, the plant $C$. reflexa could be further investigated for antidiabetic bioactive principles.

\section{Acknowledgments}

Department of Pharmacy, Primeasia University, Dhaka, Bangladesh.

\section{Authors' contributions}

Dr. Rayhan Begum conceptualized, designed and supervised the whole research work and drafting manuscript. Ronia Mostafa, Sumiya Alam, Nur Alam Siddiquee and Sonia Sultana conducted all procedures within laboratories, Rubaba Karim, Taslima Begum, Mst. Marium Begum,and Rayhana Begum compiled data, analyzed those and wrote manuscript. Finally Hongbin Wang' Rebeka Sultana, A K Lutful Kabir and Rayhana Begum critically reviewed manuscript for final approval and instructed for submission.

\section{Funding}

It is a self-funded research contributed by all authors equally.

Availability of data and materials

Authors are agreed to share raw data and materials upon request.

Ethics approval and consent to participate

The experimental procedures for our study have been approved by the Biomedical Research Center, University of Dhaka, Bangladesh (Ref. no. DPT/ BMRC/2016-2017/467). 


\section{Consent for publication}

We assure that this manuscript has not been submitted and published somewhere else. All named authors have approved the final version of manuscript and agreed with the submission.

\section{Competing interests}

The authors declare that they have no competing interests.

\section{Author details}

'Department of Pharmacy, Primeasia University, Dhaka 1213, Bangladesh. ${ }^{2}$ Department of Pharmaceutical and Biomedical Sciences, College of Pharmacy, California Northstate University, California, USA. ${ }^{3}$ Department of Pharmacy, East West University, Aftabnagar, Dhaka 1212, Bangladesh. ${ }^{4}$ School of Molecular Medical Sciences, University of Nottingham, Nottingham, UK. ${ }^{5}$ Department of Pharmaceutical Technology, Faculty of Pharmacy, University of Dhaka, Dhaka 1000, Bangladesh. ${ }^{6}$ Department of Pharmaceutical Sciences, North South University, Dhaka 1229, Bangladesh.

\section{Received: 9 June 2019 Accepted: 6 April 2020}

Published online: 12 May 2020

\section{References}

1. Shaw JE, Sicree RA, Zimmet PZ. Global estimates of the prevalence of diabetes for 2010 and 2030. Diabetes Res Clin Pract. 2010;87:4-14.

2. Kumar S, Sharma S, Vasudeva N, Ranga V. In vivo anti-hyperglycemic and antioxidant potentials of ethanol extract from Tecomella undulata. Diabetol Metab Syndr. 2012:4:33.

3. Ghosh S, Suryawanshi SA. Effect of Vinca rosea extracts in treatment of alloxan diabetes in male albino rats. Indian J Exp Biol. 2001;39:748-59.

4. Chaudhury A, Duvoor C, Dendi R, Sena V, Kraleti S, Chada A, Ravilla R, Marco A, Shekhawat NS, Montales MT, et al. Clinical review of antidiabetic drugs: implications for type 2 diabetes mellitus management. Front Endocrinol. 2017:8:1-12.

5. Bailey CJ, Day C. Traditional plant medicines as treatments for diabetes. Diabetes Care. 1989;12:553-64.

6. Einarson TR, Acs A, Ludwig C, Panton UH. Prevalence of cardiovascular disease in type 2 diabetes: a systematic literature review of scientific evidence from across the world in 2007-2017. Cardiovasc Diabetol. 2018;17:1-19.

7. Begum M, Islam A, Begum R, Uddin M, Rahman M, Alam S, et al. Ethnopharmacological inspections of organic extract of Oroxylum indicum in rat models: a promising natural gift. Evid Based Complement Altern Med. 2019;2019:1-13.

8. Begum MM, Sultana Z, Ali ME, Jami MSI, Khondkar P, Khan MM, Haque MM. Additive effect of lipid lowering drug (simvastatin) in combination with antidiabetic drug (Glibenclamide) on alloxan induced diabetic rats with long term dyslipidemia. Indian J Clin Biochem. 2014;29(4):452-61.

9. Marles RJ, Farnsworth NR. Antidiabetic plants and their active constituents. Phytomedicine. 1995;2:137-89.

10. Galehdari $H$, Negahdari S, Kesmati M, Rezaie A, Shariati G. Effect of the herbal mixture composed of Aloe vera, Henna, Adiantum capillus-veneris, and Myrrha on wound healing in streptozotocin-induced diabetic rats. BMC Complement Altern Med. 2016;16:1-9.

11. Tuhin RH, Begum MM, Rahman MS, Karim R, Begum T, Ahmed SU, Mostofa R, Hossain A, Abdel-Daim M, Begum R. Wound healing effect of Euphorbia hirta Linn. (Euphorbiaceae) in alloxan-induced diabetic rats. BMC Complement Altern Med. 2017;17:1-13.

12. Grover JK, Vats V, Rathi SS, Dawar R. Traditional Indian antidiabetic plants attenuate progression of renal damage in streptozotocin-induced diabetic mice. J Ethnopharmacol. 76: 233-38. Alberti KG, Zimmet PF. 1998. Definition, diagnosis, and classification of diabetes mellitus and its complications. Part 1: diagnosis and classification of diabetes mellitus. Provisional report of a WHO consultation. Diabet Med. 2001;15:539-53.

13. Alberti KG, Zimmet PF. Definition, diagnosis, and classification of diabetes mellitus and its complications. Part 1: diagnosis and classification of diabetes mellitus. Provisional report of a WHO consultation. Diabet Med. 1998;15:539-53.

14. Ekor M. The growing use of herbal medicines: issues relating to adverse reactions and challenges in monitoring safety. Front Pharmacol. 2014;4:1-10.

15. Patel S, Sharma V, Chauhan NS, Dixit VK. An updated review on the parasitic herb of Cuscuta reflexa Roxb. Chin J Integr Med. 2012;10:249-55.
16. Ulhas AS. Pharmacological review of Akashvel (Cuscuta Reflexa Roxb.). Int Pharmacol Res. 2015;5:152-4.

17. Machado MA, Zetsche K. A structural, functional and molecular analysis of plastids of the holoparasites Cuscuta reflexa and Cuscuta europaea. Planta. 1990;181:91-6.

18. Rai DK, Sharma V, Pal K, Gupta RK. Comparative phytochemical analysis of Cuscuta reflexa Roxb. Parasite grown on North India by GC-MS. Trop Plant Res. 2016;3:428-33.

19. Singh GS, Garg KN. Some pharmacological studies on Cuscuta reflexa plant (Akash Bel). Indian J Pharmacol. 1973;5:344-5.

20. Kayath HP, Goel NK. Effects of Cuscuta stem extract on various animal tissues. Indian J Pharmacol. 1995;27:227-9.

21. Gupta MA, Mazumder UK, Pal D, Bhattacharya S, Chakrabarty SU. Studies on brain biogenic amines in methanol extract of Cuscuta reflexa Roxb. And Corchorus olitorius Linn. Seed treated mice. Acta Pol Pharm. 2003;60:207-10.

22. Roy RK, Thakur M, Dixit VK. Development and evaluation of polyherbal formulation for hair growth-promoting activity. J Cosmet Dermatol. 2007;6:108-12.

23. Bhattacharya $\mathrm{S}$, Roy B. Preliminary investigation on antipyretic activity of Cuscuta reflexa in rats. J Adv Pharm Technol Res. 2010;1:83-7.

24. Rahman MA. Indigenous knowledge of herbal medicines in Bangladesh. 3. Treatement of skin diseases by tribal communities of the hill tracts districts. Bangladesh J Bot. 2010;39:169-77.

25. Rahmatullah M, Sultan S, Toma T, Lucky S, Chowdhury M, Haque W, Annay E, Jahan R. Effect of Cuscuta reflexa stem and Calotropis procera leaf extracts on glucose tolerance in glucose-induced hyperglycemic rats and mice. Afr J Tradit Complement Altern Med. 2010;7:109.

26. Rath D, Kar DM, Panigrahi SK, Maharana L. Antidiabetic effects of Cuscuta reflexa Roxb. In streptozotocin-induced diabetic rats. J Ethnopharmacol. 2016:192:442-9.

27. Kokate CK, Purohit AP, Gokhale SB. Carbohydrate and derived products, drugs containing glycosides, drugs containing tannins, lipids and protein alkaloids. Textbook Pharmacognosy. 2001;7:133-66.

28. Angel J, Sailesh SK, Mukkadan JK. A study on antidiabetic effect of peppermint in alloxan-induced diabetic model of Wistar rats. J Clin Biomed Sci. 2013;3:177-81.

29. Nathan DM, Singer DE, Hurxthal K, Goodson JD. The clinical information value of the glycosylated hemoglobin assay. New Eng J Med. 1984;310:3416.

30. Sharma B, Viswanath G, Salunke R, Roy P. Effects of flavonoid-rich extract from seeds of Eugenia jambolana (L.) on carbohydrate and lipid metabolism in diabetic mice. Food Chem. 2008;110:697-05.

31. Thapa BR, Walia A. Liver function tests and their interpretation. Indian J Pediatr. 2007:74:663-71.

32. Chandrasekar MJ, Bommu P, Nanjan M, Suresh B. Chemoprotective effect of Phyllanthus maderaspatensis in modulating cisplatin-induced nephrotoxicity and genotoxicity. Pharm Biol. 2006;44:100-6.

33. Begum R, Sharma M, Pillai KK, Aeri V, Sheliya MA. Inhibitory effect of Careya arborea on inflammatory biomarkers in carrageenan-induced inflammation. Pharm Biol. 2015;53:437-45.

34. Yimam M, Zhao J, Corneliusen B, Pantier M, Brownell L, Jia Q. Blood glucose lowering activity of aloe based composition, UP780, in alloxan-induced insulin dependent mouse diabetes model. Diabetol Metab Syndr. 2014;6:1-8.

35. Xu Z, Wang X, Zhou M, Ma L, Deng Y, Zhang H, Zhao A, Zhang Y, Jia W. The antidiabetic activity of total lignan from Fructus Arctii against alloxaninduced diabetes in mice and rats. Phytother Res. 2008;22:97-01.

36. Adeyi AO, Idowu BA, Mafiana CF, Oluwalana SA, Ajayi OL, Akinloye OA. Rat model of food-induced non-obese-type 2 diabetes mellitus: comparative pathophysiology and histopathology. Int J Physiol Pathophysiol Pharmacol. 2012;4:51-8.

37. Sharmin $\mathrm{R}$, Joarder HH, Alamgir M, Mostofa G, Islam M. Antidiabetic and Hepatoprotective activities of Bombax ceiba young roots in Alloxan-induced diabetic mice. J Nutrition Health Food Sci. 2018;6:1-7.

38. Karimi G, Vahabzadeh M, Lari P, Rashedinia M, Moshiri M. "Silymarin", a promising pharmacological agent for treatment of diseases. Iran J Basic Med Sci. 2011:14:308-17.

39. Sarkar A, Tiwari A, Bhasin PS, Mitra M. Pharmacological and pharmaceutical profile of gliclazide: a review. JAPS. 2011;1:11-9.

40. Štětinová V, Květina J, Pastera J, Polášková A, Pražáková M. Gliclazide: pharmacokinetic-pharmacodynamic relationships in rats. Biopharm Drug Dispos. 2007;28:241-8 
41. Palsamy P, Subramanian S. Resveratrol, a natural phytoalexin, normalizes hyperglycemia in streptozotocin-nicotinamide induced experimental diabetic rats. Biomed Pharmacother. 2008;62:598-05.

42. Hebi M, Eddouks M. Hypolipidemic activity of Tamarix articulata Vahl. In diabetic rats. J Integr Med. 2017;15:476-82.

43. Besse S, Assayag P, Delcayre C, Carre F, Cheav SL, Lecarpentier Y, Swynghedauw B. Normal and hypertrophied senescent rat heart: mechanical and molecular characteristics. Am J Physiol Heart Circ Physiol. 1993;265:H183-90

44. Vats V, Yadav SP, Grover JK. Ethanol extract of Ocimum sanctum leaves partially attenuates streptozotocin-induced alterations in glycogen content and carbohydrate metabolism in rats. J Ethnopharmacol. 2004;90:155-60.

45. Howarth FC, Jacobson M, Naseer O, Adeghate E. Short-term effects of streptozotocin-induced diabetes on the electrocardiogram, physical activity and body temperature in rats. Exp Physiol. 2005:90:237-45.

46. Al-Rawi MM. Effect of Trifolium sp. flowers extracts on the status of liver histology of streptozotocin-induced diabetic rats. Saudi J Biol Sci. 2007;14:21-8

47. Al-Shamaony L, Al-Khazraji SM, Twaij HA. Hypoglycaemic effect of Artemisia herba alba. II Effect of a valuable extract on some blood parameters in diabetic animals. J Ethnopharmacol. 1994;43:167-71.

48. Saravanan R, Pari L. Antihyperlipidemic and antiperoxidative effect of Diasulin, a polyherbal formulation in alloxan-induced hyperglycemic rats. BMC Complement Altern Med. 2005:5:1-8.

49. Bhatti R, Sharma S, Singh J, Ishar MP. Ameliorative effect of Aegle marmelos leaf extract on early stage alloxan-induced diabetic cardiomyopathy in rats. Pharm Biol. 2011:49:1137-43.

50. Attia ES, Amer AH, Hasanein MA. The hypoglycemic and antioxidant activities of garden cress (Lepidium sativum L.) seed on alloxan-induced diabetic male rats. Nat Prod Res. 2018;9:1-5.

51. Zhang JJ, Meng X, Li Y, Zhou Y, Xu DP, Li S, Li HB. Effects of melatonin on liver injuries and diseases. Int J Mol Sci. 2017;18:1-27.

\section{Publisher's Note}

Springer Nature remains neutral with regard to jurisdictional claims in published maps and institutional affiliations.

\section{Submit your manuscript to a SpringerOpen ${ }^{\circ}$ journal and benefit from:}

- Convenient online submission

- Rigorous peer review

- Open access: articles freely available online

- High visibility within the field

- Retaining the copyright to your article

Submit your next manuscript at $\boldsymbol{\nabla}$ springeropen.com 